\title{
Long-term Follow up on Patients with Neonatal Tetanus
}

\author{
Taslim S. Soetomenggolo
}

\begin{abstract}
Abstrak
Sejak tanggal 1 Januari 1978 sampai dengan tanggal 31 Desember 1985, di Bagian Ilmu Kesehatan Anak, Rumah Sakit Umum Dr. Cipto Mangunkusumo, Jakarta, telah dirawat penderita tetanus neonatorum sebanyak 405 bayi. Selama perawatan, 220 bayi meninggal dunia dan 185 bayi sembuh, tetapi hanya 85 bayi sembuh yang kembali kontrol ke rumah sakit untuk penilaian pertumbuhan dan perkembangannya. Delapan puluh lima bayi tersebut terdiri dari 51 laki-laki, dan 34 perempuan. Selama pengamatan tidak ada yang menderita kwashiorkor atau kwashiorkor marasmik. Mikrosefali didapatkan sebanyak 38,8\% pada umur 2 dan 4 bulan, dan 60,8\% pada umur 15 bulan. Perkembangan psikomotor terlambat ditemukan pada 3,5\% bayi, pada umur 2 dan 4 bulan, dan $45 \%$ pada umur 18 bulan. Tidak semua penderita dengan mikrosefali mengalami keterlambatan perkembangan psikomotor. Sebagian besar penderita menderita mikrosefali. Jumlah penderita dengan IQ normal lebih sedikit daripada populasi normal, dan IQ di bawah normal ditemukan lebih banyak daripada populasi normal. Gejala sisa terdapat pada 18,7\% penderita, terdiri dari kejang demam, epilepsi, retardasi mental ringan, hemiparesis, dan palsi serebal jenis tetraplegi.
\end{abstract}

\begin{abstract}
Between January l, 1978 and December 31, 1985, 405 patients with neonatal tetanus were hospitalized at the Department of Child Health, Dr. Cipto Mangunkusumo General Hospital, Jakarta. Of the 405 patients 220 died and 185 recovered, but only 85 patients of the survivors agreed to return for assessment of their growth and development. Of the 85 patients 51 were males, and 34 were females. During follow up none were found to suffer from kwashiorkor or marasmic kwashiorkor. Microcephaly was found in $38.8 \%$ at the age of 2 and 4 months, and $60.8 \%$ at the age of 15 months. Delayed psychomotor development was assessed by using Munchen and DDST, and it was found as low as $3.5 \%$ at the age of 2 and 4 months to as high as $45 \%$ at the age of 18 months. Not all patients with microcephaly suffered from delayed psychomotor development. The mean head circumference of male and female patients lay at or below mean minus $2 S D$, meaning most of the patients suffered from microcephaly. The number of patients with normal IQ is less than the normal population, and slow learner cases, cases with borderline mental retardation, and mild mental retardation are more numerous than the normal population. Of the 85 patients followed the sequelae were 18.7\%, consisting of febrile convulsion, epilepsy, mild mental retardatian, hemiparesis, and tetraplegic type of cerebral palsy, but the cerebral palsy may be due to kernicterus.
\end{abstract}

Keywords : Neonatal tetanus, head circumference, psychomotor development, neurological disorders.

\section{INTRODUCTION}

Generalized convulsive spasms, associated with cyanosis and apnea and consequently with brain hypoxia are a common and severe disorder found in neonatal tetanus. It is generally believed that tetanus does not leave neurological sequelae ${ }^{1}$, but some studies found about $10 \%$ cases with neurological sequela $e^{2,3}$, and brain necropsy showed severe degeneration or disappearance of the neuron. Significant neurological sequelae were found in 4 out of 9 survivors ${ }^{4}$, mild mental retardation were found in 2 out of
43 survivors ${ }^{5}$, cerebral palsy, microcephaly and mental defect were found in 2 out of 17 survivors $^{6}$, and appreciable handicaps in 4 out of 38 survivors $^{3}$. All the neurological sequelae were found in patients with severe neonatal tetanus. Brain growth and psychomotor development in children also depend on the nutritional condition ${ }^{7}$. Head circumference was smaller in patients with marasmic kwashiorkor.

The aim of this study is to assess the head circumference, psychomotor development, and the neurological disorders of the survivor of the neonatal tetanus.

Department of Child Health, Medical School, University' of Indonesia, Dr. Cipto Mangunkusumo Hospital, Jakarta, Indonesia 


\section{MATERIALS AND METHODS}

All patients were hospitalized with a clinical diagnosis of neonatal tetanus. After recovering from the disease the survivors were discharged, and were asked to return to the hospital after one week, for assessment of the head circumference, physical growth, psychomotor development, and neurological condition.

The assessment was done by the author, and follow up was performed at the age of $2,4,6,10,12,15$, $18,24,30,36$ months, and 4,5 , and 6 years. At the age of 6 years or more the patients were consulted to the psychologist to assess their psychological performance or intelligent quotient (IQ).

Electroencephalography, brain imaging, and other examinations were performed if there is indication.

\section{RESULTS}

From January 1, 1978 until December 31, 1985, 405 patients with neonatal tetanus were hospitalized at the Department of Child Health, Dr. Cipto Mangunkusumo General Hospital, Jakarta. Of the 405 patients 220 died, and 185 recovered, but only 85 patients of the survivors returned to the hospital for assessment of their growth and development. These 85 patients consisted of 51 male, and 34 female patients. None of them suffered from kwashiorkor or marasmic kwashiorkor. On admission all the patients had normal head circumference.

During long term follow-up, less than normal head circumference were found in $38.8 \%$ up to $52 \%$, delayed psychomotor development in $3.5 \%$ up to $37.5 \%$ and neurological disorders in $3.5 \%$ up to $5.2 \%$ of patients 2-12 months of age, as shown in table 1 . During this period one patient died due to bronchopneumonia.

Table 2 shows that head circumference smaller than normal was found in $56.5 \%$ up to $60.8 \%$, delayed psychomotor development in $31.3 \%$ up to $45.1 \%$, and neurological disorders in $2.8 \%$ up to $4.1 \%$ of patients 15-36 months of age.

Some clinical characteristics of the patients at the age of 4 and 5 years were depicted in table 3. Head circumference smaller than normal was found in $45.8 \%-58.9 \%$, delayed psychomotor development in $25 \%-28.6 \%$, and neurological abnormalities in $2.1 \%-3.6 \%$ of the patients.

The mean head circumferences of both male (Figure 1) and female patients (Figure 2) were approximately at or below the mean minus 2 SD (smaller than normal).

Table 1. Some clinical characteristic of the patients at the age of 2 months until 12 months

\begin{tabular}{|c|c|c|c|c|c|c|c|}
\hline \multirow[t]{2}{*}{$\begin{array}{c}\text { Age } \\
\text { (months) }\end{array}$} & \multirow[t]{2}{*}{$\begin{array}{c}\text { No. of } \\
\text { patients }\end{array}$} & \multicolumn{2}{|c|}{$\begin{array}{l}\text { Head circumference } \\
(\mathrm{cm})\end{array}$} & \multicolumn{2}{|c|}{ Psychomotor development } & \multicolumn{2}{|c|}{ Neurological status } \\
\hline & & Normal & small & Normal & Delayed & Normal & Abnormal \\
\hline 2 & 85 & 52 & $33(38.8 \%)$ & 82 & $3(3.5 \%)$ & 82 & $3(3.5 \%)$ \\
\hline 4 & 85 & 52 & $33(38.8 \%)$ & 81 & $3(3.5 \%)$ & 82 & $3(3.5 \%)$ \\
\hline 6 & 85 & 46 & $39(45.9 \%)$ & 77 & $8(9.4 \%)$ & 82 & $3(3.5 \%)$ \\
\hline 10 & 77 & 45 & $32(41,6 \%)$ & 55 & $22(28.6 \%)$ & 73 & $4(5.2 \%)$ \\
\hline 12 & 75 & 36 & $39(52 \%)$ & 47 & $28(37,5 \%)$ & 72 & $3(4 \%)$ \\
\hline
\end{tabular}

Table 2. Some clinical characteristics of patients surviving from neonatal tetanus at the age of 15 months until 36 months

\begin{tabular}{|c|c|c|c|c|c|c|c|}
\hline \multirow[t]{2}{*}{$\begin{array}{c}\text { Age } \\
\text { (months) }\end{array}$} & \multirow[t]{2}{*}{$\begin{array}{c}\text { No. of } \\
\text { patients }\end{array}$} & \multicolumn{2}{|c|}{$\begin{array}{l}\text { Head circumference } \\
(\mathrm{cm})\end{array}$} & \multicolumn{2}{|c|}{ Psychomotor development } & \multicolumn{2}{|c|}{ Neurological status } \\
\hline & & Normal & small & Normal & Delayed & Normal & Abnormal \\
\hline 15 & 74 & 29 & $45(60.8 \%)$ & 46 & $28(37.8 \%)$ & 71 & $3(4.1 \%)$ \\
\hline 18 & 71 & 30 & $41(57.7 \%)$ & 39 & $32(45.1 \%)$ & 69 & $2(2.8 \%)$ \\
\hline 24 & 71 & 29 & $42(59.2 \%)$ & 45 & $26(36.6 \%)$ & 69 & $2(2.8 \%)$ \\
\hline 30 & 69 & 30 & $39(56.5 \%)$ & 43 & $26(37.7 \%)$ & 67 & $2(2.9 \%)$ \\
\hline 36 & 64 & 26 & $38(59.4 \%)$ & 44 & $20(31.3 \%)$ & 62 & $2(3.1 \%)$ \\
\hline
\end{tabular}


Table 3. Some clinical characteristics of the patients at the age of 4 and 5 years

\begin{tabular}{|c|c|c|c|c|c|c|c|}
\hline \multirow[t]{2}{*}{$\begin{array}{l}\text { Age } \\
\text { (years) }\end{array}$} & \multirow[t]{2}{*}{$\begin{array}{l}\text { No. of } \\
\text { patients }\end{array}$} & \multicolumn{2}{|c|}{$\begin{array}{l}\text { Head circumference } \\
(\mathrm{cm})\end{array}$} & \multicolumn{2}{|c|}{ Psychomotor development } & \multicolumn{2}{|c|}{ Neurological status } \\
\hline & & Normal & small & Normal & Delayed & Normal & Abnormal \\
\hline 4 & 56 & 23 & $33(58.9 \%)$ & 40 & $16(28.6 \%)$ & 54 & $2(3.6 \%)$ \\
\hline 5 & 48 & 26 & $22(45.8 \%)$ & 36 & $12(25 \%)$ & 47 & $1(2.1 \%)$ \\
\hline
\end{tabular}

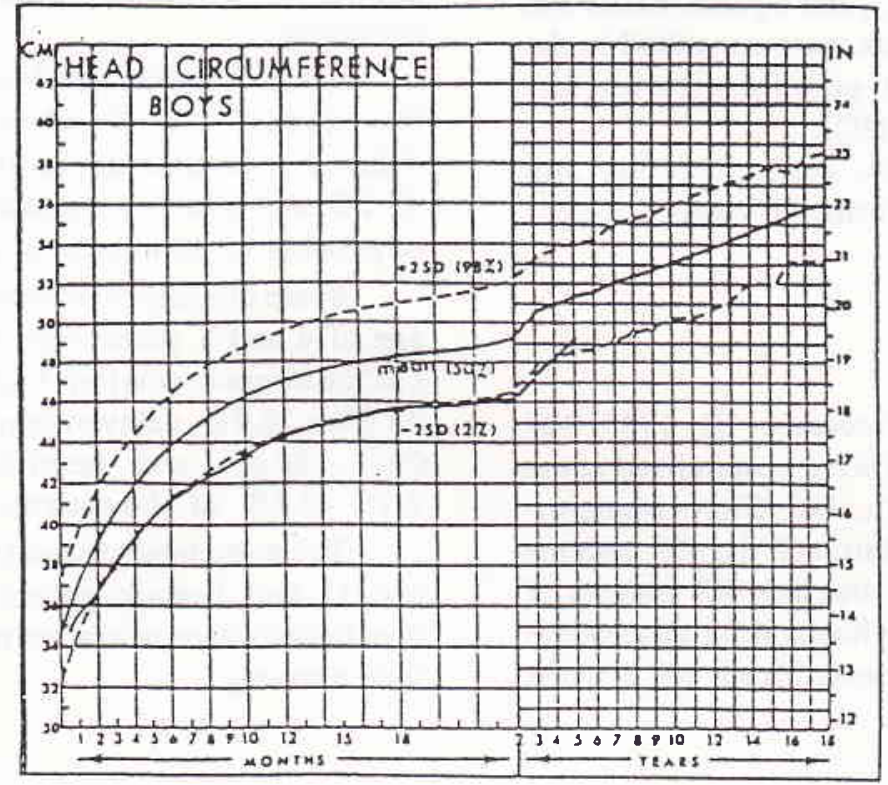

Figure 1. The mean head circumference of male patients.

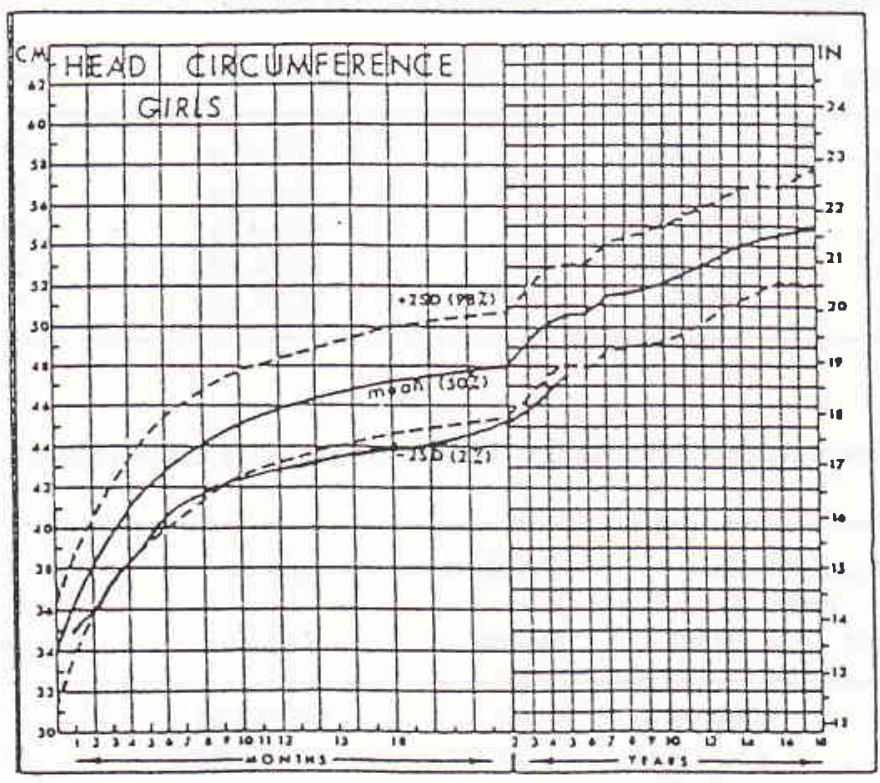

Figure 2. The mean head circumference of female patients. 
Table 4 shows the IQ of 48 patients, 18 patients (37.5\%) were normal, $20(41.7 \%)$ were slow learners, $7(14.6 \%)$ were borderline mentally retarded, and 3 (6.2\%) were mild mentally retarded. None of them suffered from severe mental retardation.

Table 5 shows the sequelae of 85 patients during follow up. Six patients suffered from febrile convulsion, 3 patients suffered from epilepsy, 3 patients suffered from mild mental retardation, 3 patients suffered from hemiparesis, and one patient suffered from tetraplegic type of cerebral palsy .

Table 4. The results of psychological evaluation in 48 patients at the age of 6 years or more

\begin{tabular}{lcrr}
\hline \multicolumn{1}{c}{ IQ } & $\begin{array}{c}\text { No. of } \\
\text { patients }\end{array}$ & $\%$ & $\begin{array}{c}\text { Normal } \\
\text { population } \\
(\%)\end{array}$ \\
\hline Normal & 18 & 37.5 & 49.4 \\
Slow learner & 20 & 41.7 & 16.2 \\
Borderline mental retardation & 7 & 14.6 & 6.0 \\
Mild mental retardation & 3 & 6.2 & $<2.2$ \\
\hline Total & 48 & 100.0 & \\
\hline
\end{tabular}

Table 5. The Sequelae of 85 patients during follow up

\begin{tabular}{lcc}
\hline Sequelae & No. of patients & $\%$ \\
\hline Febrile convulsion & 6 & 7.1 \\
Epilepsy & 3 & 3.5 \\
Mild mental retardation & 3 & 3.5 \\
Hemiparesis & 3 & 3.5 \\
Tetraplegic type of cerebral palsy & 1 & 1.1 \\
\hline Total & 16 & 18.7 \\
\hline
\end{tabular}

\section{DISCUSSION}

Generalized convulsive spasms, associated with cyanosis and apnea and consequently with brain hypoxia are a common and severe disorder in neonatal tetanus. This hypoxia might be the cause of the growth retardation of the brain, consequently microcephaly and delayed psychomotor development will happen, but tables 1 and 2 showed that not all patients with microcephaly suffered from delayed psychomotor development. The number of patients with delayed psychomotor development were less than those with microcephaly. This finding was similar to the finding of Lou ${ }^{8}$. Usually microcephaly with brain damage will cause delayed psychomotor development, and finally these patients will suffer from mental retardation. In neonatal tetanus only patients with severe and prolonged hypoxia will suffer from delayed psychomotor development and mental retardation ${ }^{6}$.

Figures 1 and 2 shows the mean head circumference of male and female patients. On admission the mean head circumference was normal but during follow up the mean head circumference was at or below the line of mean minus $2 \mathrm{SD}$; this condition might be due to hypoxia of the brain during hospitalization. During hospitalization the patients suffered from frequent convulsive spasms, cyanosis and apnea, and these conditions will cause brain hypoxia. If the hypoxia is severe and prolonged it will cause the death of patients or recovery with microcephaly and mental retardation. On psychological evaluation (Table 4), the normal IQ is found in only $37.5 \%$ of patients, and this figure is smaller than the normal population. The figures of slow learners, cases with borderline mental retardation and with mild mental retardation are higher than the normal population ${ }^{10}$. This condition might be caused by brain hypoxia. If we compare with other studies this condition is beticr; in this report none of the patients suffered from moderate or severe mental retardation. The neurological sequelae of this study is in $18.7 \%$ of patients (table 5 ). This figure is higher than in other studies which reported about $10 \%$ of neurological sequelae ${ }^{2,3}$. Febrile convulsions were found in $7.1 \%$ of patients, this figure is also higher than in other studies, some authors reported the percentage of febrile convulsions was about $2-5 \%{ }^{11,12}$. One patient in this study suffered from tetraplegic type of cerebral palsy. During hospitalization this patient suffered from hyperbilirubinemia with the serum bilirubin of $29.4 \mathrm{mg} / \mathrm{dl}$, and also suffered from kernicterus. The clinical characteristics of this patient showed that the cerebral palsy was not due to the neonatal tetanus but due to the kernicterus. At the age of 11 months this patient died due to bronchopneumonia.

\section{CONCLUSIONS}

A long term follow up was carried out on 85 patients with neonatal tetanus. Most of them suffered from microcephaly but not all patients with microcephaly suffered from delayed psychomotor development.

On psychological evaluation only one patient suffered from mild mental retardation, and none of them suffered from moderate and severe mental retardation.

The neurological sequelae are found in $18.7 \%$ of patients, and most of them suffered from febrile convulsion $(7.1 \%)$, and one patient suffered from tetra- 
plegic type of cerebral palsy but this disorder was caused by kernicterus.

\section{REFERENCES}

1. Marshall FN. Tetanus of the newborn. Adv Pediatr 1968; 15 : 65-110.

2. Smythe P M. Studies on neonatal tetanus and on pulmonary compliance of the totally relaxed infant. $\mathrm{Br}$ Med J 1963; 1 : 565-71.

3. Teknetzi P, Manios S, Katsouyanopoulos. Neonatal tetanuslong-term residual handicaps, Arch Dis Child 1983; 1: 68-9.

4. Huault G. Tetanos du nouveau-ne'. Traitement par la ventilation artificielle et la curarisation prolongee. Thesis, Paris 1964 (Cited by Teknetzi et al, 1983).

5. Salimpour R. Cause of death in tetanus neonatorum. Arch Dis Child 1977; 52: 587-94.
6. Khoo B, Lee E L, Lam K L. Neonatal tetanus treated with high dosage diazepam. Arch Dis Child 1978; 53: 737-9.

7. Engsner G, Habte D, Sjogren I, Vahlquist B. Brain growth in children with kwashiorkor. Arch Paediatr Scand 1974; 63: 687-94.

8. Lou H C. Developmental neurology. New York: Raven Press $1982 ; 1-80$.

9. Soetomenggolo T S, Dwi Putro Widodo, Passat J, Ismail S. Blood gas analysis in neonatal tetanus. Paediatr Indones 1994; 34: 44-7.

10. Swaiman K F. Mental retardation. In: Swaiman K F, Ed, Pediatric neurology principles and practice. Toronto: $\mathrm{C} \mathrm{V}$ Mosby 1989; 115-28.

11. Aicardi J. Epilepsy in children. New York: Raven Press 1986; 183-204.

12. Solomon G E, Kutt H, Plum F. Clinical management of seizures, 2nd ed. 1983; 253-7. 